Article

\title{
The Seasonal Variation of the Chemical Composition of Essential Oils from Porcelia macrocarpa R.E. Fries (Annonaceae) and Their Antimicrobial Activity
}

\author{
Erica Biolcati P. da Silva ${ }^{1}$, Marisi G. Soares ${ }^{2}$, Bruna Mariane ${ }^{1}$, Marcelo A. Vallim ${ }^{1}$, \\ Renata C. Pascon ${ }^{1}$, Patricia Sartorelli ${ }^{1}$ and João Henrique G. Lago ${ }^{1{ }^{1} *}$
}

1 Instituto de Ciências Ambientais, Químicas e Farmacêuticas, Universidade Federal de São Paulo, Diadema 09972-270, SP, Brazil; E-Mails: ericabiolcati@gmail.com (E.B.P.S.); bruna_mariane@yahoo.com.br (B.M.); marcelo.vallim@gmail.com (M.A.V.); renata.pascon@gmail.com (R.C.P.); psartorelli@unifesp.br (P.S.) Instituto de Química, Universidade Federal de Alfenas, Alfenas 37130-000, MG, Brazil; E-Mail: marisigs@gmail.com

* Author to whom correspondence should be addressed; E-Mail: joao.lago@unifesp.br; Tel.: +55-11-3319-3300; Fax: +55-11-4043-6428.

Received: 22 August 2013; in revised form: 22 October 2013 / Accepted: 24 October 2013 / Published: 1 November 2013

\begin{abstract}
This study investigates the impact of seasonal variation on the chemical composition of essential oils from the leaves of Porcelia macrocarpa (Annonaceae) obtained over the course of one year (January-December 2011) and the chemical composition of the essential oils obtained from the ripe fruits of the same plant. Furthermore, the essential oils of the leaves were investigated with respect to their antimicrobial activity. The essential oils of the leaves contain a mixture of monoterpenes, one diterpene and several sesquiterpenes. The main components were identified as the sesquiterpenes germacrene D $(29 \%-50 \%)$ and bicyclogermacrene $(24 \%-37 \%)$. No significant variation was observed for the composition of the essential oil of the leaves over the course ofthe year, except for the month of November, when the ripe fruit were collected. In this month, substantially decreased concentrations of germacrene D $(28.8 \pm 0.8 \%)$ and bicyclogermacrene $(23.9 \pm 0.6 \%)$ were measured and the emergence of spathulenol $(10.4 \pm 0.2 \%)$ was observed. The essential oils extracted from the ripe fruit revealed the presence of a variety of monoterpenes, sesquiterpenes and hydrocarbons. The main constituents of these oils were neryl $(8.8 \pm 0.2 \%)$ and geranyl $(27.3 \pm 0.7 \%)$ formates, $\gamma$-muurolene $(10.3 \pm 0.9 \%)$ and dendrolasin $(8.23 \pm 0.06 \%)$. The antimicrobial activity of
\end{abstract}


the essential oil obtained from the leaves of $P$. macrocarpa towards a range of bacterial and yeast strains was examined. In order to determine the minimum inhibitory concentration (MIC) of essential oils obtained from the January collection of the leaves, broth microdilution assays were carried out, which showed a significant antimicrobial activity towards Cryptococcus neoformans serotypes A and D as well as C. gattii serotypes $\mathrm{B}$ and $\mathrm{C}$.

Keywords: Porcelia macrocarpa; essential oils; seasonal variation; antimicrobial activity; C. neoformans

\section{Introduction}

Porcelia macrocarpa R.E. Fries (Annonaceae) is a tree found in the forest regions on the Atlantic coast and in the interior of Brazil [1]. The chemical composition of various parts of P. macrocarpa has already been the subject of several scientific studies. High contents of acetylene acetogenins were found in the extracts from seeds [2], while several amides, lignanamides, and alkaloids were isolated from branch extracts [3-5]. The branches also contained several interesting polar compounds, such as flavonoids, trimethylamonium salts and amino acids [6]. Essential oils extracted from the leaves were analyzed by GC/MS which allowed the identification of nine individual components, of which bicyclogermacrene (27.5\%) and germacrene D (37.8\%) were the major components [7]. A desirable cytotoxic activity against human tumor cells was observed for these essential oils [8].

Essential oils are not only used in several therapeutic applications of folk medicine, but they also form part of a variety of modern pharmaceutical remedies [9]. However, a meticulous qualitative as well as quantitative analysis of these essential oils is of the utmost importance, since the quality of the macroscopic remedy is highly sensitive towards several factors, e.g., climatic conditions, the chemo- and biotype as well as the phenology of the plant [10]. Important biological activities have already been reported for essential oils of several species of Annonaceae [11] and our group has investigated the composition and biological activity of essential oils obtained from several other Brazilian plants [12-14]. The promising results of these studies encouraged us to examine the influence of the seasonal variation on the chemical composition of the essential oils of the leaves of P. macrocarpa. Furthermore, we were interested in a comparison between the chemical composition of these essential oils with the chemical composition of essential oils obtained from the ripe fruits of the same plant and an examination of the antimicrobial activity of leaves oil.

\section{Results and Discussion}

\subsection{Microclimatic Factors}

Generally, the temperature pattern for Sao Paulo city can be divided into two periods: a colder period from ca. April-October and a warmer period from November-March. The precipitation pattern is inversely proportional to the temperature profile and minimum rainfall can usually be observed between the months of April-September. The temperature for the collection period of 2011 
(see Figure 1) basically follows these temperature/precipitation averages, except for August 2011, which was unusually hot, and June 2011, which showed unusually high precipitation [15].

Figure 1. Average monthly temperatures $\left({ }^{\circ} \mathrm{C}\right)$ and precipitation $(\times 10 \mathrm{~mm})$ values in 2011 (collection period).

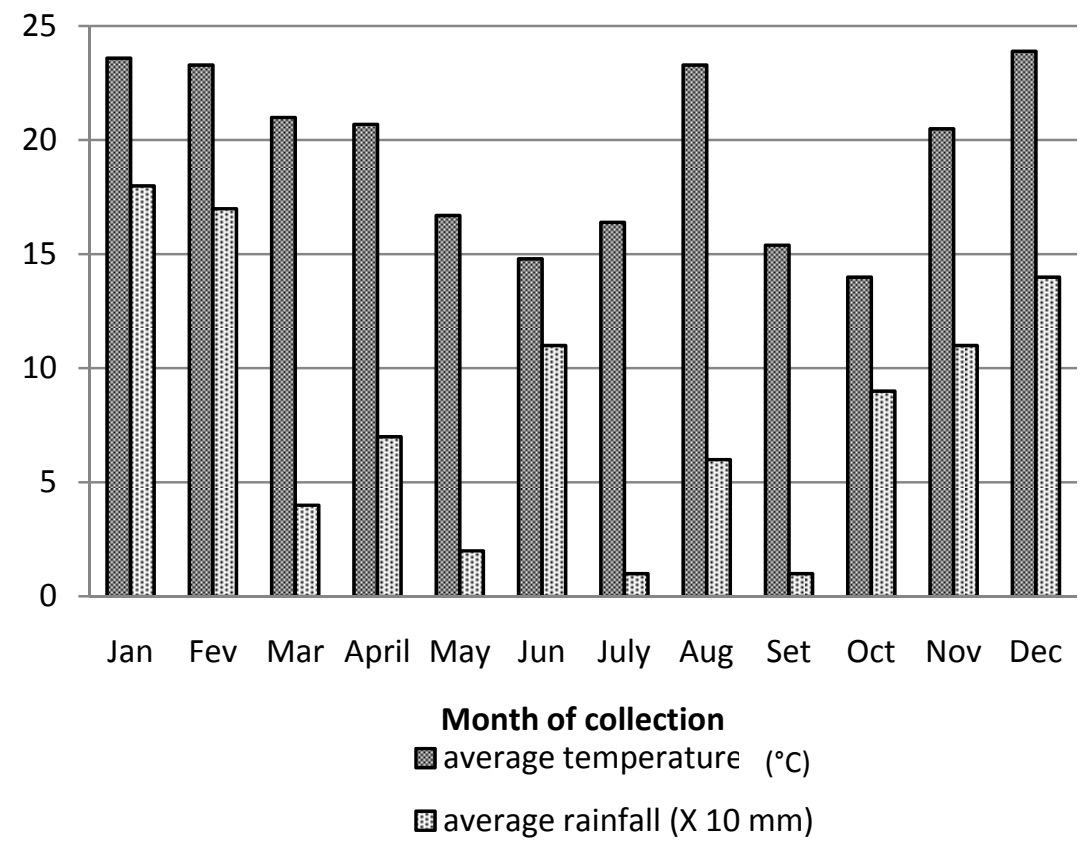

For the collection period of the leaves of P. macrocarpa, the average temperature of the warmer period (January-April and November-December) was $22.2^{\circ} \mathrm{C}$. The average temperature of the colder period from May-October was $16.7{ }^{\circ} \mathrm{C}$. The precipitation pattern showed a maximum around December-February (monthly average of $150 \mathrm{~mm}$ ) and a minimum around May, July and September (average of $10-20 \mathrm{~mm}$ ).

\subsection{Extraction Yields of the Essential Oils from the Leaves of P. macrocarpa}

Essential oils were extracted from the leaves by hydro-distillation as described in the Experimental section (Section 3.4) and the extraction yields are summarized in Figure 2. We found that extraction yields of essential oils from the leaves of $P$. macrocarpa are subject to seasonal changes, reflected in high yields obtained during the months of April $(0.07 \pm 0.04 \%)$, June $(0.08 \pm 0.02 \%)$, August $(0.07 \pm 0.01 \%)$ and September $(0.07 \pm 0 \%)$. Interestingly, the extraction yield decreased in November $(0.03 \pm 0 \%)$, which typically coincides with the month of fructification for this species. An impact of environmental factors on the yields of essential oils was also observed for several species such as Rosmarinus officinalis [16], Mentha suaveolens [17], Satureja horvatii [18], and Baccharis trimera [19]. The influence of several other climatic factors such as temperature and pluviometric index onto the extraction yield also needs to be taken into consideration [10]. For example, the observed precipitation during January and February was significantly higher compared to the other months of 2011. In contrast to that, the temperature remained relatively constant over the course of the study, except for the months of May, June and October. As shown in Figure 2, the maximum oil yields were obtained 
around June and minimum yields were obtained in December/January. This would suggest an inversely proportional relation between oil extraction yields and the temperature and precipitation pattern. Similar findings have been reported by Gazim et al. [20], who showed that the amount of several volatile compounds produced by Tetradenia riparia (Lamiaceae) were affected by temperature, humidity and rainfall changes over the course of different seasons. Moreover, Lago et al. reported that the relative amounts of essential oils from the leaves of Pittosporium undulatum could be better correlated to microclimatic parameters such as temperature and precipitation index, than to the phenology of the studied species [21]. The yield of essential oils from the fruit of P. macrocarpa, obtained during November 2011 was $0.05 \pm 0.01 \%$ and is comparable to the average yield $(0.06 \pm 0.02 \%)$ obtained from the leaves (see Figure 2$)$.

Figure 2. Monthly extraction yields of the essential oils from the leaves of Porcelia macrocarpa (January-December/2011).

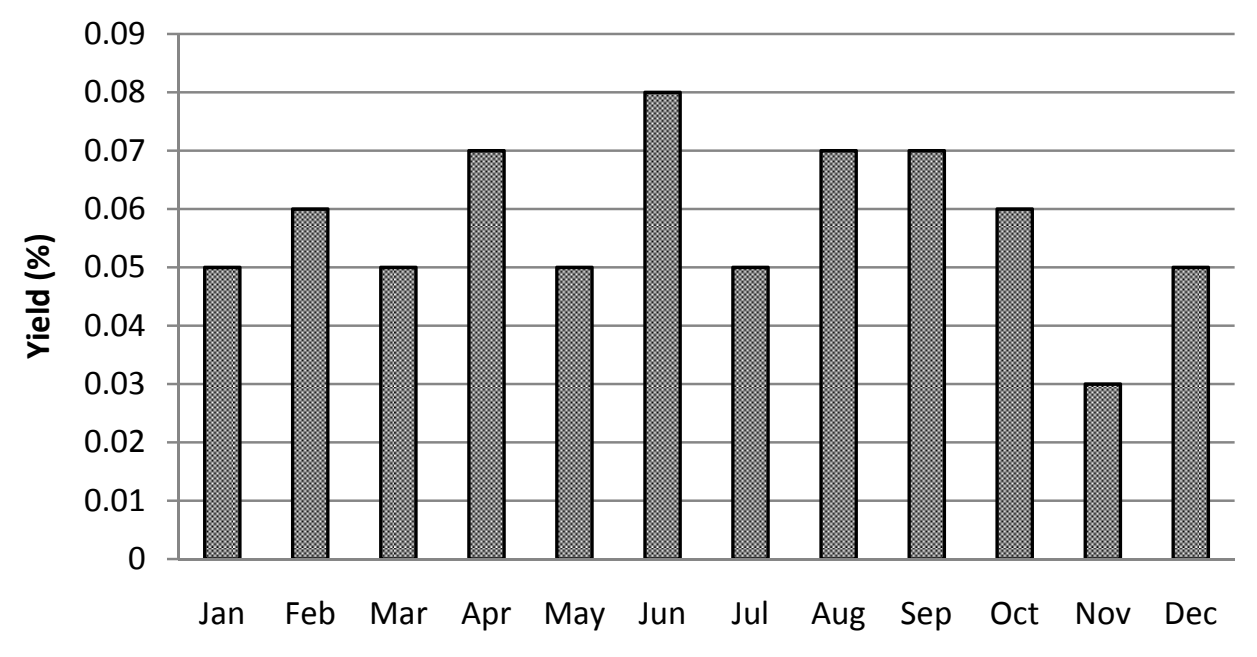

Month of collection

\subsection{Chemical Composition of the Essential Oils Obtained from the Leaves and the Ripe Fruit of P. macrocarpa}

The crude essential oils obtained from the leaves and the ripe fruits of $P$. macrocarpa were analyzed by GC (DB-5 capillary column) and GC-MS. Individual compounds were assigned according to their Kovats indices in conjunction with a comparison of the experimentally obtained mass spectra to those described in library (NIST 107) and in the literature [22]. In the essential oils of the leaves, nine individual components were observed and identified as verbanyl acetate (monoterpene), $\alpha$-copaene, iso-longifolene, $\beta$-cedrene, $\alpha$-guainene, germacrene $\mathrm{D}$, bicyclogermacrene, and spathulenol (sesquiterpenes) as well as phytol (diterpene). The main compounds were germacrene D $(28.8 \pm 0.8 \%-49.6 \pm 0.7 \%)$ and bicyclogermacrene $(23.9 \pm 0.6 \%-36.8 \pm 0.5 \%)$. The sum of these nine components accounted for between $66.6 \pm 0.1 \%$ (November) and $91.1 \pm 0.6 \%$ (April) of the total oil content (see Table 1). The overall composition was similar to previously described samples $[7,8]$. A significant decrease $(p<0.05)$ of the relative amounts of germacrene D $(28.8 \pm 0.8 \%)$ and bicyclo-germacrene $(23.9 \pm 0.6 \%)$ was detected during November 2011, concomitant with the 
emergence of spathulenol $(10.4 \pm 0.2 \%)$, which could not be detected in any other month. As reported by Bülow and Köning, the presence of spathulenol and the reduced amounts of germacrene D and bicyclogermacrene could be partially explained by biochemical factors, such as the enzymatic oxidation of the latter compounds to form spathulenol [23]. This process could therefore be related directly to the phenology of P. macrocarpa, since it coincides with the end of the fructification period. However, it is worth pointing out here, that during the sterile period, the relative amounts of germacrene D and bicyclogermacrene were also non-constant (67 $\pm 7 \%$ in February to $84 \pm 2 \%$ in April), which could be attributed to microclimatic factors, e.g., temperature and precipitation [24]. As shown in Table 1 and Figure 2, the sum of relative proportion of both sesquiterpenes was lower in January, February and December $(71 \pm 7 \%, 67 \pm 7 \%$ and $78.9 \pm 0.7 \%$, respectively) compared to the other months. For these months, relatively high precipitation values $(14-18 \mathrm{~mm})$ and temperatures $\left(23-24{ }^{\circ} \mathrm{C}\right)$ were observed. These observations suggest an influence of these microclimatic factors on the production and/or accumulation of germacrene $\mathrm{D}$ and bicyclogermacrene in the crude essential oils.

The essential oils from the ripe fruit consisted of 65 individual components (Table 2), which accounted for $99.6 \pm 0.9 \%$ of the volatile components. The dominant compounds were monoterpenes (ca. $45 \%)$, especially neryl $(8.8 \pm 0.2 \%)$ and geranyl $(27.3 \pm 0.7 \%)$ formates. Other major fractions consisted of sesquiterpenes, such as $\gamma$-muurolene $(10.3 \pm 0.9 \%), \delta$-cadinene $(2.44 \pm 0.03 \%)$ and dendrolasin $(8.23 \pm 0.06 \%)$ as well as hydrocarbons such as hexacosane $(6.02 \pm 0.06 \%)$ and heptacosane $(2.13 \pm 0.06 \%)$.

\subsection{Antimicrobial Activity}

Several species of the Annonaceae are known to produce essential oils which display antimicrobial activity, e.g., Annona vepretorum [25], Duguetia lanceolata [26], Guatteriopsis blepharophylla, G. friesiana, and G. hispida [27]. In order to determine the antimicrobial activity of the essential oils obtained from the leaves and the ripe fruit of $P$. macrocarpa, the minimum inhibitory concentration (MIC concentration range: $0.003-1.0 \mathrm{mg} / \mathrm{mL}$ ) was ascertained for the prokaryote and eukaryote microbes. No biological activity could be observed for the essential oils obtained from the fruit, since no inhibition was detected at $1.0 \mathrm{mg} / \mathrm{mL}$. The essential oils from the leaves (collected in January 2011) however, displayed significant biological activity towards all four Cryptococcus strands tested. No biological activity was detected for the prokaryotes tested as well as for the several Candida spp. or $S$. cerevisiae. The most sensitive strand is $C$. neoformans serotype $\mathrm{D}$, which exhibited a growth inhibition rate of $85 \%$ at a dose of $0.06 \mathrm{mg} / \mathrm{mL}$ essential oil (see Table 3). Another clinically very important strain is $C$. neoformans serotype A, which accounts for most of the cases of cryptococosis found among immunosuppressed patients. The essential oils of the leaves showed an inhibition rate of $80 \%$ against this strain for a dose of $0.5 \mathrm{mg} / \mathrm{mL}$ essential oil. The remaining strains of $C$. gattii serotypes $\mathrm{B}$ and $\mathrm{C}$ are pathogens, which usually affect immunocompetent patients, and required higher concentrations of around $1.0 \mathrm{mg} / \mathrm{mL}$ essential oil in order to cause inhibition rates of $98 \%$ and $61 \%$, respectively. C. gattii presented a lower inhibition at the maximum concentration tested and not the traditional $80 \%$ inhibition, however, we found important to report this result. The observed MICs for all four strains were in accordance with literature values [28,29], suggesting a high accuracy of the assay. Fluconazole was used as positive control. 
Table 1. Seasonal variation of the chemical composition of essential oils obtained from the leaves of Porcelia macrocarpa (monthly collection from January to December 2011).

\begin{tabular}{|c|c|c|c|c|c|c|c|c|c|c|c|c|c|}
\hline \multirow[b]{2}{*}{ Compound $^{\mathrm{a}}$} & \multicolumn{13}{|c|}{ Relative amount (\%) ${ }^{\mathrm{b}}$} \\
\hline & KI & January & February & March & April & May & June & July & August & September & October & November & December \\
\hline verbanyl acetate & 1340 & $0.39 \pm 0.04^{\mathrm{a}}$ & $0.43 \pm 0.01^{\mathrm{a}}$ & $0.40 \pm 0.01^{\mathrm{a}}$ & $0.46 \pm 0.06^{\mathrm{a}}$ & $0.51 \pm 0.02^{\mathrm{a}}$ & $0.42 \pm 0.01^{\mathrm{a}}$ & $0.42 \pm 0.04^{\mathrm{a}}$ & $0.41 \pm 0.03^{\mathrm{a}}$ & $1.76 \pm 0.96^{\mathrm{a}}$ & $0.34 \pm 0.01^{\mathrm{a}}$ & $0.31 \pm 0.19^{\mathrm{a}}$ & $0.38 \pm 0.01^{\mathrm{a}}$ \\
\hline$\alpha$-copaene & 1376 & $2.0 \pm 0.3^{\mathrm{a}}$ & $1.6 \pm 0.9^{\mathrm{a}}$ & $2.05 \pm 0.07^{\mathrm{a}}$ & $2.2 \pm 0.2^{\mathrm{a}}$ & $1.9 \pm 0.8^{\mathrm{a}}$ & $1.95 \pm 0.02^{\mathrm{a}}$ & $2.01 \pm 0.09^{\mathrm{a}}$ & $1.8 \pm 0.2^{\mathrm{a}}$ & $2.4 \pm 0.9^{\mathrm{a}}$ & $1.71 \pm 0.01^{\mathrm{a}}$ & $0.4 \pm 0.2^{\mathrm{b}}$ & $2.07 \pm 0.05^{\mathrm{a}}$ \\
\hline iso-longifolene & 1387 & $1.4 \pm 0.1^{\mathrm{a}}$ & $1.5 \pm 0.1^{\mathrm{a}}$ & $1.9 \pm 0.1^{\mathrm{a}}$ & $2.0 \pm 0.9^{\mathrm{a}}$ & $1.8 \pm 0.9^{\mathrm{a}}$ & $0.9 \pm 0.8^{b}$ & $0.50 \pm 0.02^{\mathrm{b}}$ & $0.53 \pm 0.02^{b}$ & $1.8 \pm 0.9^{\mathrm{a}}$ & $1.2 \pm 0.7^{\mathrm{b}}$ & $0.6 \pm 0.2^{b}$ & $0.23 \pm 0.01^{\mathrm{b}}$ \\
\hline$\beta$-cedrene & 1418 & $0.72 \pm 0.06^{\mathrm{a}}$ & $0.80 \pm 0.07^{\mathrm{a}}$ & $0.75 \pm 0.01^{\mathrm{a}}$ & $0.9 \pm 0.1^{\mathrm{a}}$ & $1.3 \pm 0.4^{b}$ & $1.4 \pm 0.4^{\mathrm{b}}$ & $1.08 \pm 0.02^{\mathrm{b}}$ & $1.1 \pm 0.1^{\mathrm{b}}$ & $0.96 \pm 0.01^{\mathrm{a}}$ & $0.85 \pm 0.09^{\mathrm{a}}$ & $0.6 \pm 0.3^{\mathrm{a}}$ & $0.85 \pm 0.02^{\mathrm{a}}$ \\
\hline$\alpha$-guaiene & 1439 & $0.9 \pm 0.3^{\mathrm{a}}$ & $1.1 \pm 0.3^{\mathrm{a}}$ & $0.71 \pm 0.01^{\mathrm{a}}$ & $0.56 \pm 0.03^{b}$ & $0.52 \pm 0.07^{\mathrm{b}}$ & $0.61 \pm 0.08^{\mathrm{b}}$ & $0.43 \pm 0.01^{\mathrm{b}}$ & $0.61 \pm 0.02^{\mathrm{b}}$ & $0.61 \pm 0.01^{\mathrm{b}}$ & $0.4 \pm 0.2^{\mathrm{b}}$ & $0.41 \pm 0.07^{\mathrm{b}}$ & $0.89 \pm 0.01^{\mathrm{a}}$ \\
\hline germacrene $\mathrm{D}$ & 1480 & $40 \pm 7^{\mathrm{a}}$ & $39 \pm 7^{\mathrm{a}}$ & $46.3 \pm 0.4^{\mathrm{a}}$ & $47 \pm 1^{\mathrm{a}}$ & $49.6 \pm 0.7^{b}$ & $47.1 \pm 0.9^{\mathrm{a}}$ & $49 \pm 2^{b}$ & $45 \pm 1^{\mathrm{a}}$ & $46.6 \pm 0.1^{\mathrm{a}}$ & $43 \pm 3^{a}$ & $28.8 \pm 0.8^{b}$ & $46.2 \pm 0.7^{\mathrm{a}}$ \\
\hline bicyclogermacrene & 1494 & $31 \pm 3^{\mathrm{a}}$ & $28 \pm 7^{\mathrm{a}}$ & $34.2 \pm 0.3^{\mathrm{a}}$ & $37 \pm 1^{\mathrm{a}}$ & $34 \pm 2^{\mathrm{a}}$ & $36.8 \pm 0.5^{\mathrm{a}}$ & $32 \pm 2^{\mathrm{a}}$ & $30.8 \pm 0.2^{\mathrm{a}}$ & $32.5 \pm 0.1^{\mathrm{a}}$ & $35 \pm 3^{\mathrm{a}}$ & $23.9 \pm 0.6^{b}$ & $32.7 \pm 0.3^{\mathrm{a}}$ \\
\hline spathulenol & 1576 & 0 & 0 & 0 & 0 & 0 & 0 & 0 & 0 & 0 & 0 & $10.4 \pm 0.2$ & 0 \\
\hline phytol & 1955 & $7.3 \pm 0.9^{\mathrm{a}}$ & $18 \pm 2^{\mathrm{b}}$ & $3.2 \pm 0.2^{\mathrm{c}}$ & $1.2 \pm 0.3^{\mathrm{d}}$ & $0.55 \pm 0.05^{\mathrm{d}}$ & $0.45 \pm 0.04^{\mathrm{d}}$ & $0.6 \pm 0.2^{\mathrm{d}}$ & 0 & $0.7 \pm 0.5^{\mathrm{d}}$ & $0.6 \pm 0.2^{\mathrm{d}}$ & $1.24 \pm 0.04^{\mathrm{d}}$ & $0.55 \pm 0.01^{\mathrm{d}}$ \\
\hline monoterpenes & & $0.39 \pm 0.04$ & $0.43 \pm 0.01$ & $0.40 \pm 0.01$ & $0.46 \pm 0.06$ & $0.51 \pm 0.02$ & $0.42 \pm 0.01$ & $0.42 \pm 0.04$ & $0.41 \pm 0.03$ & $1.76 \pm 0.96$ & $0.34 \pm 0.01$ & $0.31 \pm 0.19$ & $0.38 \pm 0.01$ \\
\hline sesquiterpenes & & $76 \pm 3$ & $72 \pm 3$ & $85.9 \pm 0.2$ & $89.4 \pm 0.7$ & $88.6 \pm 0.6$ & $88.7 \pm 0.4$ & $85 \pm 1$ & $79.5 \pm 0.6$ & $84.8 \pm 0.5$ & $82 \pm 1$ & $65.0 \pm 0.3$ & $80.7 \pm 0.5$ \\
\hline diterpene & & $7.3 \pm 0.9$ & $18 \pm 2$ & $3.2 \pm 0.2$ & $1.2 \pm 0.3$ & $0.55 \pm 0.05$ & $0.45 \pm 0.04$ & $0.6 \pm 0.2$ & 0 & $0.7 \pm 0.5$ & $0.6 \pm 0.2$ & $1.24 \pm 0.04$ & $0.55 \pm 0.01$ \\
\hline TOTAL & & $84 \pm 2$ & $90 \pm 3$ & $89.6 \pm 0.1$ & $91.1 \pm 0.6$ & $90 \pm 1$ & $89.6 \pm 0.4$ & $89 \pm 1$ & $79.9 \pm 0.4$ & $86.8 \pm 0.3$ & $83.7 \pm 0.7$ & $66.6 \pm 0.1$ & $82.1 \pm 0.3$ \\
\hline
\end{tabular}

${ }^{a}$ Individual compounds were assigned according to their Kovats indices in conjunction with a comparison of the experimentally obtained mass spectra to those described in library (NIST 107) and in the literature [22]; ${ }^{b}$ Values in the same line with different subscript (a, b, c, and d) are significantly different within months of collection; $\mathrm{t}:(p<0.05)$. All values displayed represent the mean value \pm standard deviation of three independent experiments. Statistical analyses were performed by analysis of variance (ANOVA) using the BIOESTAT 5.0 (Stat Soft Inc., Tulsa, OK, USA) software package. A probability value of $p<0.05$ was considered statistically significant. 
Table 2. The chemical composition of essential oils obtained from the ripe fruit of Porcelia macrocarpa (November 2011).

\begin{tabular}{|c|c|c|}
\hline Compound $^{\mathrm{a}}$ & KI & Relative amount (\%) ${ }^{\mathrm{b}}$ \\
\hline$o$-cymene & 1026 & $0.09 \pm 0.01$ \\
\hline benzene acetaldehyde & 1042 & $0.15 \pm 0.02$ \\
\hline$\gamma$-terpinene & 1059 & $0.18 \pm 0.06$ \\
\hline oct- $2 E$-en-1-ol & 1066 & $0.12 \pm 0.02$ \\
\hline dehydrolinalool & 1090 & $0.06 \pm 0.01$ \\
\hline non-3Z-en-1-ol & 1157 & $0.06 \pm 0.01$ \\
\hline terpinen-4-ol & 1177 & $0.09 \pm 0.02$ \\
\hline methyl salicylate & 1191 & $0.12 \pm 0.03$ \\
\hline dec-2E-enal & 1263 & $0.09 \pm 0.02$ \\
\hline geranial & 1267 & $0.18 \pm 0.01$ \\
\hline neryl formate & 1282 & $8.8 \pm 0.2$ \\
\hline geranyl formate & 1298 & $27.3 \pm 0.7$ \\
\hline dimethoxy-Z-citral & 1318 & $0.13 \pm 0.05$ \\
\hline dimethoxy- $E$-citral & 1341 & $1.26 \pm 0.03$ \\
\hline ethyl nerolate & 1354 & $0.99 \pm 0.01$ \\
\hline$Z$ - $\alpha$-damascone & 1358 & $0.66 \pm 0.02$ \\
\hline neryl acetate & 1361 & $0.84 \pm 0.01$ \\
\hline$\alpha$-ylangene & 1375 & $1.14 \pm 0.01$ \\
\hline geranyl acetate & 1381 & $0.51 \pm 0.02$ \\
\hline$\beta$-bourbonene & 1388 & $1.12 \pm 0.02$ \\
\hline$E$ - $\alpha$-damascone & 1393 & $0.75 \pm 0.03$ \\
\hline ethyl geranate & 1395 & $0.21 \pm 0.01$ \\
\hline$E$-caryophyllene & 1419 & $1.14 \pm 0.01$ \\
\hline$\beta$-duprezianene & 1422 & $0.56 \pm 0.06$ \\
\hline neryl acetone & 1436 & $0.50 \pm 0.03$ \\
\hline$E$ - $\beta$-farnesene & 1456 & $2.8 \pm 0.7$ \\
\hline$\gamma$-muurolene & 1479 & $10.3 \pm 0.9$ \\
\hline$\alpha$-amorphene & 1484 & $0.63 \pm 0.03$ \\
\hline cis-eudesma-6,11-diene & 1489 & $1.17 \pm 0.03$ \\
\hline$\alpha$-muurolene & 1500 & $0.69 \pm 0.01$ \\
\hline butylated hydroxytoluene & 1515 & $0.96 \pm 0.01$ \\
\hline$\delta$-cadinene & 1523 & $2.44 \pm 0.03$ \\
\hline trans-cadina-1,4-diene & 1534 & $0.3 \pm 0.02$ \\
\hline$\alpha$-cadinene & 1538 & $0.40 \pm 0.02$ \\
\hline$\alpha$-calacorene & 1545 & $0.27 \pm 0.01$ \\
\hline$E$-nerolidol & 1563 & $1.03 \pm 0.05$ \\
\hline dendrolasin & 1571 & $8.23 \pm 0.06$ \\
\hline globulol & 1590 & $1.08 \pm 0.03$ \\
\hline viridiflorol & 1592 & $0.33 \pm 0.01$ \\
\hline cubeban-11-ol & 1595 & $0.21 \pm 0.01$ \\
\hline geranyl 2-methylbutanoate & 1601 & $0.48 \pm 0.01$ \\
\hline geranyl isovalerate & 1607 & $0.30 \pm 0.03$ \\
\hline
\end{tabular}


Table 2. Cont.

\begin{tabular}{|c|c|c|}
\hline Compound $^{\mathrm{a}}$ & KI & Relative amount (\%) ${ }^{\mathrm{b}}$ \\
\hline 5-epi-7-epi- $\alpha$-eudesmol & 1607 & $0.48 \pm 0.02$ \\
\hline himachalol & 1653 & $0.78 \pm 0.01$ \\
\hline$\alpha$-cadinol & 1654 & $0.92 \pm 0.01$ \\
\hline E-bisabol-11-ol & 1667 & $0.45 \pm 0.02$ \\
\hline$\gamma$-dodelactone & 1677 & $0.8 \pm 0.1$ \\
\hline$Z$-nerolidyl acetate & 1677 & $0.45 \pm 0.01$ \\
\hline$\alpha$-bisabolol & 1685 & $0.99 \pm 0.07$ \\
\hline davanol acetate & 1689 & $0.30 \pm 0.01$ \\
\hline $2 E, 6 E$-farnesol & 1743 & $0.15 \pm 0.02$ \\
\hline$\beta$-bisabolenal & 1769 & $0.15 \pm 0.01$ \\
\hline 1-octadecene & 1790 & $1.6 \pm 0.7$ \\
\hline$n$-hexadecanol & 1875 & $1.38 \pm 0.01$ \\
\hline $5 E, 9 E$-farnesyl acetone & 1913 & $0.18 \pm 0.03$ \\
\hline isophytol & 1947 & $0.30 \pm 0.03$ \\
\hline 3Z-cembrene A & 1966 & $0.63 \pm 0.01$ \\
\hline ethyl hexadecanoate & 1993 & $0.54 \pm 0.02$ \\
\hline$E, E$-geranyl linalool & 2027 & $0.21 \pm 0.06$ \\
\hline manool & 2057 & $0.48 \pm 0.04$ \\
\hline$n$-octadecanol & 2077 & $0.39 \pm 0.02$ \\
\hline$E$-phytol acetate & 2218 & $1.14 \pm 0.02$ \\
\hline pentacosane & 2500 & $1.86 \pm 0.03$ \\
\hline hexacosane & 2600 & $6.02 \pm 0.06$ \\
\hline heptacosane & 2700 & $2.13 \pm 0.06$ \\
\hline monoterpenes & & $44.8 \pm 0.9$ \\
\hline sesquiterpenes & & $37.1 \pm 0.9$ \\
\hline diterpenes & & $0.51 \pm 0.06$ \\
\hline hydrocarbons & & $10.49 \pm 0.06$ \\
\hline other compounds & & $6.7 \pm 0.1$ \\
\hline TOTAL & & $99.6 \pm 0.9$ \\
\hline
\end{tabular}

${ }^{a}$ Individual compounds were assigned according to their Kovats indices in conjunction with a comparison of the experimentally obtained mass spectra to those described in library (NIST 107) and in the literature [22];

${ }^{\mathrm{b}}$ Values displayed represent the mean value \pm standard deviation of three independent experiments.

Table 3. Minimum inhibitory concentrations (MICs) obtained from broth microdilution assays for essential oils from the leaves of Porcelia macrocarpa (January 2011).

\begin{tabular}{ccc}
\hline Microorganism & Essential oil dosage $(\mathbf{m g} / \mathbf{m L})$ & Positive Control \\
\cline { 3 - 3 } & $0.50(80 \pm 18 \%)$ & Fluconazole $(\mathbf{m g} / \mathbf{m L})$ \\
\hline C. neoformans (serotype A) & $0.06(95 \pm 8 \%)$ & 0.013 \\
C. neoformans (serotype D) & $1.00(98 \pm 6 \%)$ & 0.006 \\
C. gattii (serotype B) & $1.00(61 \pm 1 \%) *$ & 0.025 \\
C. gattii (serotype C) & 0.006 \\
\hline
\end{tabular}

Numbers in parenthesis represent the mean percentage inhibition at each MIC \pm standard deviation.

* $61 \%$ inhibition does not represent $\mathrm{MIC}_{80}$ in this case. 
In addition to the desirable antimicrobial activity, previous reports have also reported a beneficial antifungal activity for some monoterpenes, diterpenes and sesquiterpenes (especially germacrene D and bicyclogermacrene), which were found in the essential oils of other plants [30-33]. For example, Cabral et al. showed that germacrene D, the main compound in Vitex rivularis oil, displayed a significant activity against dermatophytes [34]. Bicyclogermacrene and $\alpha$-copaene have moreover been associated with an antifungal activity, mainly in studies involving the genus Candida and dermatophytes [31,34-37]. To the best of our knowledge, there are no reports in the scientific literature describing the activity of the essential oils (or their main components) of the leaves of $P$. macrocarpa against $C$. neoformans and $C$. gattii, which cause fungal meningitisin immunocompromised as well as immunocompetent patients [38,39].

\section{Experimental}

\subsection{Chemical Reagents}

All solvents used were of analytical grade and purchased from CAAL (São Paulo, Brazil). Linear $n$-alkane $\left(\mathrm{C}_{8}-\mathrm{C}_{20}\right)$ reference standards, as well as all culture media and standard antibiotic discs of fluconazole and chloramphenicol were obtained from Sigma-Aldrich Chemical Co. (St. Louis, MO, USA). All other chemicals were purchased from Merck (Darmstadt, Germany), except for hygromycin B, which was obtained from Invitrogen (Carlsbad, CA, USA).

\subsection{Microclimatic Factors}

Temperatures were measured in situ with a digital Pocket Weather Meter Kestrel 3000 (Nielsen-Kellerman, Boothwyn, PA, USA). Precipitation values (in $\mathrm{mm}$ ) were measured during each period of collection (from 12th to 18th day) using a pluviometer, which was custom-made in our laboratory.

\subsection{Plant Material}

Leaves of P. macrocarpa R.E. Fries (Annonaceae) were collected randomly from three individual trees in the Jardim Botânico de São Paulo (São Paulo, SP, Brazil) at 12 a.m. on the 15th day of each month (January to December 2011). Ripe fruit samples were collected from the very same trees on 15th November, 2011 at 12 a.m. Reference specimen were deposited at the herbarium of the Instituto de Botânica (São Paulo, Brazil) and compared with those under reference SP76791. Samples of the crude oils are available from the authors.

\subsection{Hydro-Distillation of the Essential Oils}

Each batch of fresh leaves or fruitsamples from $P$. macrocarpa was hydro-distilled for four hours in a Clevenger type apparatus [21]. The essential oils were extracted from the aqueous fraction using $\mathrm{CH}_{2} \mathrm{Cl}_{2}(3 \times 5 \mathrm{~mL})$. The combined organic fractions were subsequently dried over anhydrous $\mathrm{Na}_{2} \mathrm{SO}_{4}$, before the solvent was evaporated and the oil was stored at $4{ }^{\circ} \mathrm{C}$ in the absence of light. 


\subsection{Gas Chromatography Analysis (GC)}

The crude essential oils were analyzed by GC, using a Shimadzu GC-2010 gas chromatograph, equipped with an FID-detector and an automatic injector (Shimadzu AOC-20i). As the stationary phase, an RtX-5 capillary column (5\% phenyl, 95\% polydimethylsiloxane, $30 \mathrm{~m} \times 0.32 \mathrm{~mm} \times 0.25 \mu \mathrm{m}$ film thickness; Restek, Bellefonte, PA, USA) was used with helium as the carrier gas (flow rate: $1 \mathrm{~mL} / \mathrm{min}$ ). The oven temperature was raised from $60{ }^{\circ} \mathrm{C}$ to $280{ }^{\circ} \mathrm{C}$ at a rate of $3{ }^{\circ} \mathrm{C} / \mathrm{min}$ and subsequently kept at $280{ }^{\circ} \mathrm{C}$ for further ten minutes. The injector temperature was $220{ }^{\circ} \mathrm{C}$ and the detector (FID) was kept at $280{ }^{\circ} \mathrm{C}$. Composition percentages were obtained from electronic integration of the FID output and a series of linear $n$-alkanes $\left(\mathrm{C}_{8}-\mathrm{C}_{20}\right)$, which were used as reference points for the determination of the Kovats indices (KI).

\subsection{Gas Chromatography-Mass Spectrometry (GC-MS) Analysis}

GC-MS analysis was carried out using a Shimadzu GC-17A chromatograph connected to a MS-QP-5050A mass spectrometer. The GC analysis was carried out with an RtX-5 capillary column (5\% phenyl, $95 \%$ polydimethylsiloxane, $30 \mathrm{~m} \times 0.32 \mathrm{~mm} \times 0.25 \mu \mathrm{m}$ film thickness; Restek, Bellefonte, PA, USA) and the operating conditions were identical with those described in the previous section. Retention indices for all compounds were determined according to the Kovats indices (KI), as described in the previous section. The EI-MS analysis was carried out under an ionization voltage of $70 \mathrm{eV}$ and an ion source temperature of $230{ }^{\circ} \mathrm{C}$. The identification of individual compounds was achieved by a comparison of the KI values in conjunction with matching mass spectrometric fragmentation patterns to those of mass spectra library (NIST 107), published MS fragmentation patterns [22] and/or MS spectra of authentic compounds.

\subsection{Microbial Strain Media, Antibiotics and Growth Conditions}

In order to test the antimicrobial activity of the essential oils obtained from the leaves and fruits of P. macrocarpa, Gram-positive (Streptococcus equi-CBMAI 264, Staphylococcus epidermidisCBMAI 604, and Enterococcus fecalis), Gram-negative (Escherichia coli, Serratia marcescensCBMAI 469, and Pseudomonas aeruginosa-CBMAI 602) and yeast (Candida dubliniensis-ATCC 7978, C. tropicalis-ATCC 13803, C. albicans-ATCC 18804/CBMAI 560, C. glabrata-ATCC 90030, C. parapsilosis-clinical isolate 68, C. krusei-clinical isolate 9602, Cryptococcus neoformansKN99a serotype A/JEC21 serotype D, C. gattii-NIH312 serotype C/R265 serotype B, and Saccharomyces cerevisiae - BY4742) strains were subjectedto a broth microdilution assays. Microbial strains were kept as criostocks at $-80{ }^{\circ} \mathrm{C}$, cultivated onYEPD ( $2 \%$ peptone, $2 \%$ dextrose and $2 \%$ agar) platesfor yeasts (1\% yeast extract) or $\mathrm{LB}(1 \%$ tryptone, $1 \% \mathrm{NaCl}$ and $2 \%$ agar) for bacterial strains $(0.5 \%$ bacterial strains). Fluconazole and chloramphenicol were used as positive controls for yeast and bacteria, respectively. Essential oils were diluted to 10\% with dimethylsulfoxide (DMSO).

\subsection{Broth Microdilution Assay for the Determination of Minimum Inhibitory Concentrations (MIC)}

Micro titer plates (96 wells) were used for broth microdilution assays in order to ascertain the MIC for each tested strain. Two independent assays were conducted according to the guidelines of the 
National Committee for Clinical Laboratory Standards (CLSI, M100-S9). The following minor modifications were implemented: the target microorganisms were grown in test tubes overnight in $3 \mathrm{~mL}$ of the respective medium (RPMI 1640 for yeast and $\mathrm{BHI}$ for bacteria) at $30{ }^{\circ} \mathrm{C}$ and agitated in a rotary shaker $(150 \mathrm{rpm})$. The cellular concentration was adjusted to $1 \times 10^{2}-2 \times 10^{2} \mathrm{CFU}$ (yeast) and $1 \times 10^{4}-2 \times 10^{4} \mathrm{CFU}$ (bacteria) per well. The concentration was confirmed by viability counts on YEPD and LB plates. Nine dilutions of essential oils and reference standards were used (two-fold serial dilutions). A negative sterilization control, containing medium only and a positive growth control, containing cells and $10 \mu \mathrm{L}$ DMSO (100\% growth) were also included. Microtiter plates were subsequently incubated at $30{ }^{\circ} \mathrm{C}$ for 24 or $48 \mathrm{~h}$, respectively. Finally, the absorbance at $530 \mathrm{~nm}$ was measured in a plate reader (Epoch, Bio-Tek, Winooski, VT, USA). The threshold for the MIC was set at a minimum of an $80 \%$ growth inhibition. All tests were performed in triplicate in $100 \mu \mathrm{L}$ of reaction volume. The concentration range for the essential oils of the leaves ranged from $0.003-1.0 \mathrm{mg} / \mathrm{mL}$. Fluconazole and chloramphenicol concentrations ranged between 0.0007 and $0.05 \mathrm{mg} / \mathrm{mL}$ and 0.00312 and $0.400 \mathrm{mg} / \mathrm{mL}$, respectively.

\section{Conclusions}

A great benefit of this study is the characterization of the composition of the essential oils of the leaves and ripe fruits of $P$. macrocarpa. The biological activity documented in this study should be of great pharmacological interest, since the major components of the essential oils may now be tested individually against both species of the Cryptococcus genus, which continue to cause life-threatening diseases and demand new potent antifungal drugs in order to allow effective treatment.

\section{Acknowledgments}

The authors would like to thank the CNPq (300546/2012-2) and the FAPESP (2011/51739-0) for providing financial support and fellowships.

\section{Conflicts of Interest}

The authors declare no conflict of interest.

\section{References}

1. Murray, N.A. Revision of Cymbopetalum and Porcelia (Annonaceae). Syst. Bot. Monogr.1993, 40, 121-140.

2. Chaves, M.H.; Roque, N.F. Acetogenins from Porcelia macrocarpa: Stereochemical determination of 2-alkyl-3-hydroxy-4-methyl $\gamma$-lactones by ${ }^{13} \mathrm{C}$-NMR spectroscopy. Phytochemistry 1997, 44, 523-528.

3. Chaves, M.H.; Roque, N.F. Amides and lignanamides from Porcelia macrocarpa. Phytochemistry 1997, 46, 879-881.

4. Chaves, M.H.; Santos, L.A.; Lago, J.H.G.; Roque, N.F. Alkaloids from Porcelia macrocarpa. J. Nat. Prod. 2001, 64, 240-242. 
5. Lago, J.H.G.; Chaves, M.H.; Ayres, M.C.C.; Agripino, D.G.; Young, M.C.M. Evaluation of antifungal and DNA-damaging activities of alkaloids from branches of Porcelia macrocarpa. Planta Med. 2007, 73, 292-295.

6. Chaves, M.H.; Freitas, A.; Roque, N.F.; Cavalheiro, A.J. Separação e identificação de constituintes químicos polares dos galhos de Porcelia macrocarpa. Quím. Nova 2000, 23, 307-309.

7. Chaves, M.H.; Lago, J.H.G.; Roque, N.F. Macrocarpane, a new sesquiterpene skeleton from the leaves of Porcelia macrocarpa. J. Braz. Chem. Soc. 2003, 14, 16-19.

8. Silva, E.B.P.; Matsuo, A.L.; Figueiredo, C.R.; Chaves, M.H.; Sartorelli, P.; Lago, J.H.G. Chemical constituents and cytotoxic evaluation of essential oils from leaves of Porcelia macrocarpa (Annonaceae). Nat. Prod. Commun. 2013, 8, 277-279.

9. Nakatsuo, T.; Lupo, A.T., Jr.; Chinn, J.W., Jr.; Kang, R.K.L. Biological activity of essential oils and their constituents. Bioact. Nat. Prod. 2000, 21, 571-631.

10. Gobo-Neto, L.; Lopes, N.P. Plantas medicinais: Fatores de influência no conteúdo de metabólitos secundários. Quím. Nova 2007, 30, 374-381.

11. Silva, A.A.C.A.; Souza, E.A.; Matsuo, A.L.; Lago, J.H.G.; Chaves, M.H. Intraspecific variation and cytotoxic evaluation of the essential oils from Oxandra sessiliflora R. E. Fries. J. Med. Plant Res. 2013, 7, 504-508.

12. Sartorelli, P.; Santana, J.S.; Guadagnin, R.C.; Lago, J.H.G.; Pinto, E.G.; Tempone, A.G.; Stefani, H.A.; Soares, M.G.; Silva, A.M. In vitro trypanocidal evaluation of pinane derivatives from essential oils of ripe fruits from Schinus terebinthifolius Raddi (Anacardiaceae). Quím. Nova 2012, 35, 743-747.

13. Bou, D.D.; Lago, J.H.G.; Figueiredo, C.R.; Matsuo, A.L.; Guadagnin, R.C.; Soares, M.G.; Sartorelli, P. Chemical composition and cytotoxicity evaluation of essential oil from leaves of Casearia sylvestris, its main compound $\alpha$-zingiberene and derivatives. Molecules 2013, 18, 9477-9887.

14. Lago, J.H.G.; Carvalho, L.A.C.; da Silva, F.S.; Toyama, D.D.; Favero, O.A.; Romoff, P. Chemical composition and anti-inflammatory evaluation of essential oils from leaves and stem barks from Drimys brasiliensis Miers (Winteraceae). J. Braz. Chem. Soc. 2010, 21, 1760-1765.

15. INMET (Brazilian National Institute of Meteorology) Database. Available online: http://www.inmet.gov.br (accessed on 15th September 2012).

16. Lakusić, D.; Ristić, M.; Slavkovska, V.; Lakusić, B. Seasonal variations in the composition of the essential oils of rosemary (Rosmarinus officinalis, Lamiaceae). Nat. Prod. Commun. 2013, 8, 131-134.

17. El-Kashoury, S.A.; El-Askary, H.I.; Kandil, Z.A.; Salem, M.A.; Sleem, A.A. Chemical composition and biological activities of the essential oil of Mentha suaveolens Ehrh. Z. Naturforsch. C 2012, 67, 571-579.

18. Lakušić, B.; Ristić, M.; Slavkovska, V.; Milenković, M.; Lakušić, D. Environmental and seasonal impacts on the chemical composition of Satureja horvatii Šilić (Lamiaceae) essential oils. Chem. Biodivers. 2011, 8, 483-493.

19. Silva, F.G.; Oliveira, C.B.A.; Pinto, J.E.B.P.; Nascimento, V.E.; Santos, S.C.; Seraphin, J.C.; Ferri. P.H. Seasonal variability in the essential oils of wild and cultivated Baccharis trimera. J. Braz. Chem. Soc. 2007, 18, 990-997. 
20. Gazim, Z.C.; Amorim, A.C.L.; Hovell, A.M.C.; Rezende, C.M.; Nascimento, I.A.; Ferreira, G.A.; Cortez, D.A.G. Seasonal variation, chemical composition, and analgesic and antimicrobial activities of the essential oils from leaves of Tetradenia riparia (Hochst.) Coddin Southern Brazil. Molecules 2010, 15, 5509-5524.

21. Lago, J.H.G.; Fávero, O.A.; Romoff, P. Microclimatic factors and phenology influences in the chemical composition of the essential oils from Pittosporum undulatum Vent. leaves. J. Braz. Chem. Soc. 2006, 17, 1334-1338.

22. Adams, R.P. Identification of Essential Oil Components by Gas Chromatography/Mass Spectrometry, 4th ed.; Allured Publishing Corporation: Carol Stream, IL, USA, 2008.

23. Bülow, N.; König, W.A. The role of germacrene D as a precursor in sesquiterpene biosynthesis: Investigations of acid catalyzed, photochemically and thermally induced rearrangements. Phytochemistry 2000, 55, 141-168.

24. Pala-Paul, J.; Perez-Alonso, M.J.; Velasco-Negueruela, A.; Pala-Paul, R.; Sanz, J.; Conejero, F. Seasonal variation in chemical constituents of Santolina rosmarinifolia L. ssp. rosmarinifolia. Biochem. Syst. Ecol. 2001, 29, 663-672.

25. Costa, E.V.; Dutra, L.M.; Nogueira, P.C.; Moraes, V.R.; Salvador, M.J.; Ribeiro, L.H.; Gadelha, F.R. Essential oil from the leaves of Annona vepretorum: Chemical composition and bioactivity. Nat. Prod. Commun. 2012, 7, 265-266.

26. Sousa, O.V.; Del-Vechio-Vieira, G.; Alves, M.S.; Araújo, A.A.; Pinto, M.A.; Amaral, M.P.; Rodarte, M.P.; Kaplan, M.A. Chemical composition and biological activities of the essential oils from Duguetia lanceolata St. Hil. barks. Molecules 2012, 17, 11056-11066.

27. Costa, E.V.; Teixeira, S.D.; Marques, F.A.; Duarte, M.C.; Delarmelina, C.; Pinheiro, M.L.; Trigo, J.R.; Sales-Maia, B.H. Chemical composition and antimicrobial activity of the essential oils of the Amazon Guatteriopsis species. Phytochemistry 2008, 69, 1895-1899.

28. Espinel-Ingroff, A. In vitro antifungal activities of anidulafungin and micafungin, licensed agents and the investigational triazole posaconazole as determined by NCCLS methods for 12,052 fungal isolates: review of the literature. Rev. Iberoam. Micol. 2003, 20, 121-136.

29. Lago, J.H.G.; Souza, E.D.; Mariane, B.; Pascon, R.; Vallim, M.A.; Martins, R.C.; Baroli, A.A.; Carvalho, B.A.; Soares, M.G.; dos Santos, R.T.; et al. Chemical and biological evaluation of essential oils from two species of Myrtaceae-Eugenia uniflora L. and Plinia trunciflora (O. Berg) Kausel. Molecules 2011, 16, 9827-9837.

30. Rodrigues, F.F.; Oliveira, L.G.; Rodrigues, F.F.; Saraiva, M.E.; Almeida, S.C.; Cabral, M.E.; Campos, A.R.; Costa, J.G. Chemical composition, antibacterial and antifungal activities of essential oil from Cordia verbenacea DC leaves. Pharmacogn. Res. 2012, 4, 161-165.

31. Verma, R.S.; Padalia, R.C.; Chauhan, A. Volatile constituents of Origanum vulgare L., 'thymol' chemotype: Variability in North India during plant ontogeny. Nat. Prod. Res. 2012, 26, 1358-1362.

32. Cordeiro, R.A.; Nogueira, G.C.; Brilhante, R.S.; Teixeira, C.E.; Mourão, C.I.; Castelo-Branco Dde, S.; Paiva, M.A.; Ribeiro, J.F.; Monteiro, A.J.; Sidrim, J.J.; et al. Farnesol inhibits in vitro growth of the Cryptococcus neoformans species complex with no significant changes in virulence-related exoenzymes. Vet. Microbiol. 2012, 159, 375-380. 
33. Marongiu, B.; Piras, A.; Porcedda, S.; Falconieri, D.; Gonçalves, M.J.; Salgueiro, L.; Maxia, A.; Lai, R. Extraction, separation and isolation of volatiles from Vitex agnus-castus L. (Verbenaceae) wild species of Sardinia, Italy, by supercritical $\mathrm{CO}_{2}$. Nat. Prod. Res. 2010, 24, 569-579.

34. Cabral, C.; Gonçalves, M.; Cavaleiro, C.; Sales, F.; Boyom, F.; Salgueiro, L. Composition and anti-fungal activity of the essential oil from Cameroonian Vitex rivularis Gurke. Nat. Prod. Res. 2009, 23, 1478-1484.

35. Fontenelle, R.O.; Morais, S.M.; Brito, E.H.; Brilhante, R.S.; Cordeiro, R.A.; Nascimento, N.R.; Kerntopf, M.R.; Sidrim, J.J.; Rocha, M.F. Antifungal activity of essential oils of Croton species from the Brazilian Caatinga biome. J. Appl. Microbiol. 2008, 104, 1383-1390.

36. Gallori, S.; Bilia, A.R.; Mulinacci, N.; Bicchi, C.; Rubiolo, P.; Vincieri, F.F. Identification of volatile constituents of Tambourissa leptophylla. Planta Med. 2001, 67, 290-292.

37. Costa, E.V.; Dutra, L.M.; de Jesus, H.C.; Nogueira, P.C.; Moraes, V.R.; Salvador, M.J.; Cavalcanti, S.C.; dos Santos, R.L.; Prata, A.P. Chemical composition and antioxidant, antimicrobial, and larvicidal activities of the essential oils of Annona salzmannii and A. pickelii (Annonaceae). Nat. Prod. Commun. 2011, 6, 907-912.

38. Li, S.S.; Mody, C.H. Cryptococcus. Proc. Am. Thorac. Soc. 2010, 7, 186-196.

39. Lin, X.; Heitman, J. The biology of the Cryptococcus neoformans species complex. Ann. Rev. Microbiol. 2006, 60, 69-105.

Sample Availability: Samples of essential oils from leaves and fruits of P. macrocarpa are available from the authors.

(C) 2013 by the authors; licensee MDPI, Basel, Switzerland. This article is an open access article distributed under the terms and conditions of the Creative Commons Attribution license (http://creativecommons.org/licenses/by/3.0/). 